\title{
ERIOCAULON L. from Brazil: An annotated checklist and taxonomic novelties ${ }^{1}$
}

\author{
Adriana Luiza Ribeiro de Oliveira ${ }^{1,2^{*}}$ and Claudia Petean Bove ${ }^{2}$
}

Received: June 23, 2014 Accepted: November 11, 2014

\begin{abstract}
Eriocaulon is an aquatic and cosmopolitan genus with 478 species. It is characterized by diplostemonous flowers and free petals with a black gland at the apex. There are few taxonomists studying Eriocaulon from Brazil. The species of this genus remain barely delimited, with inconsistent descriptions, and nomenclatural types not assigned or located. The analysis of nomenclatural types, specimens in scientific collections, and protologues enabled the recognition of 53 species of Eriocaulon from Brazil. Thirteen new synonyms and the elevation of five varietes to species level are proposed. Comments on taxonomy, geographic distribution, habitat, life form, and conservation category are provided.
\end{abstract}

Keywords: conservation category, ecological traits, Eriocaulaceae, flora from Brazil, taxonomy.

\section{Introduction}

Eriocaulon is an aquatic and cosmopolitan genus with 478 species (Giulietti \& Hensold 1990; Govaerts 2006) distributed mainly in the tropics. In Brazil, it occurs throughout the country in all domains, and reaches its greatest diversity in the Cerrado. The genus is characterized by diplostemonous flowers and free petals with a black gland at the apex (Giulietti \& Hensold 1990). Eriocaulon from Brazil was first mentioned in the Flora Fluminensis, where Vellozo (1827) described Eriocaulon ligulatum as Dupatya ligulata. Bongard (1831) subsequently provided brief descriptions of 80 species of Eriocaulon from Brazil, but only E. crassiscapum and E. elichrysoides remained in this genus. The others species were transferred to different genera of this family. Körnicke (1863) in the Flora Brasiliensis treated 32 species of Eriocaulon. Kunth (1841), Ruhland (1901; 1903), and Silveira (1908; 1928), among others, also described species from this country. Giulietti (1978a; 1978b) studied members of Eriocaulon from the Serra do Cipó and provided new circumscriptions for $E$. melanocephalum and E. aquatile. The genus has also been studied in regional floras and checklists from the Amazon Forest (Costa \& Giulietti 1999), Atlantic Forest (Moldenke \& Smith 1976; Giulietti 2012), Caatinga (Giulietti 1986; Giulietti \& Parra 1995; Miranda \& Giulietti 2001), and Cerrado (Giulietti 1978a; Giulietti \& Hensold 1987; Giulietti et al. 1996; Ferreira et al. 2011). However, many species remain inadequately delimited, with inconsistent descriptions, and few identification keys exist; some nomenclatural types have not been selected or cannot be located. Therefore, the recognition of these species is sometimes difficult, with consequences for the establishment of conservation categories. Currently, 57 species and 13 varieties of Eriocaulon from Brazil are accepted (Giulietti et al. 2013). This study presents a new general assessment of the genus in this country. We recognize 53 species of Eriocaulon from Brazil. Thirteen new synonyms and elevation of five varietes to species level are proposed. Comments on taxonomy, geographic distribution, habitat, life form, and conservation category are provided.

\section{Material and methods}

We analyzed specimens from the following herbaria: BHCB, CESJ, HUEFS, HUFU, INPA, UB, OUPR, P, R, RB, SP and SPF (Thiers, continuously updated); as well as material collected in the Cerrado and Caatinga from the Espinhaço mountain range (states of Minas Gerais and Bahia), and in the Cerrado from the states of Goiás and Tocantins. The database SpeciesLink (2014) also has been consulted. The collected material was deposited in the Herbarium of the Museu Nacional (R). The checklist of Eriocaulon L. was developed after careful study of the nomenclatural types housed in the R and the Jardim Botânico do Rio de Janeiro (RB) herbaria, as well as the online images, available

\footnotetext{
${ }^{1}$ Part of first author's PhD thesis

${ }^{2}$ Programa de Pós Graduação em Botânica, Museu Nacional, Universidade Federal do Rio de Janeiro, Cidade Universitária, Quinta da Boa Vista, São Cristóvão, 20940-040, Rio de Janeiro, RJ, Brazil

*Corresponding author: ribeirosenna1@gmail.com
} 
on the internet, of the types from the following herbaria: $\mathrm{B}$, BR, CAL, G, HBG, K, M, NY, P, S, TEX-LL and US (Thiers, continuosly updated). The protologues were also analyzed. Whenever possible, one voucher for each domain of occurrence was selected, which most closely matched the morphological characters described in the protologue and/or collected in the type locality. There is no mention of selected material when only the type was seen or when no voucher was found. Only well known synonyms are cited. The species were considered to represent distinct evolutionary lineages (Queiroz 2007). To delimit these entities, we assumed that each species has a unique set of characters (Davis \& Nixon 1992). The conservation categories were established according to IUCN (2012): with their respective acronyms. The geographic domains are according to IBGE (2004). The states where the species occur have been abbreviated as follows: Acre (AC), Amapá (AP), Amazonas (AM), Bahia (BA), Goiás (GO), Maranhão (MA), Mato Grosso (MT), Mato Grosso do Sul (MS), Minas Gerais (MG), Pará (PA), Paraná (PR), Pernambuco (PE), Piauí (PI), Rio de Janeiro (RJ), Rondônia (RO), Santa Catarina (SC), São Paulo (SP), Tocantins (TO), Rio Grande do Sul (RS), and Roraima (RR) as well the Distrito Federal (DF).

\section{Results and discussion}

1.Eriocaulon alto-gibbosum Ruhland, Bot. Jahrb. Syst. 30: 146. 1901. Type: BRAZIL. Mato Grosso, 23/VI/1899, R. Pilger 757 (B "photo !").

Eriocaulon gibbosum var. mattogrossense Ruhland, Bot. Jahrb. Syst. 30: 146. 1901. Type: BRAZIL. Mato Grosso, 4/V/1899, R. Pilger 586 (B "photo !"), syn. nov.

This species occurs in the Cerrado (BA, GO, MT, and TO). It is emergent, living on river banks. It was not found in conservation units. Because this species has a large extent of geographic occurrence, the conservation rating of Least Concern (LC) is proposed.

Eriocaulon alto-gibbosum can be recognized by: membranaceous leaves with a red sheath; hemispherical capitula with vegetative reproduction; pistillate flowers with gibbous sepals, incrassate gibba and ventral petal slightly longer than the lateral ones.

According to Govaerts (2006), Eriocaulon gibbosum var. matogrossense is a synonym of E. gibbosum (not E. altogibbosum). Nonetheless, Giulietti et al. (2013) considered it as an accepted taxon. Although Eriocaulon alto-gibbosum has a highly variable morphology (Ruhland 1903), we noted that specimens under the name of E. gibbosum var. matogrossense have the same exclusive set of characters states of E. alto-gibbosum whereas E. gibbosum is $10-15 \mathrm{~cm}$ high, has incrassate leaves with a green sheath, and no vegetative reproduction in capitula, justifying the synonymy.

Selected material: BRAZIL. Tocantins: Dianópolis, 07/ VI/2009, fl. fr., A. Oliveira et al. 257 (R).
2. Eriocaulon aquatile Körn., Fl. Bras. 3(1): 495. 1863. Type: BRAZIL. Minas Gerais: Serra de Santo Antônio, VIII/1818, Martius s.n. (M "photo !").

Eriocaulon angustifolium Körn., Fl. Bras. 3(1): 495. 1863. Type: BRAZIL. Goiás: "chapada de N. S. d’abadia", V/1848, Gardner 4382 (K "photo !").

Eriocaulon cipoense Silveira, Flora e Serras Mineiras 33-34. 1908. Type: BRAZIL. Minas Gerais: Serra do Cipó, IV/1905, A. Silveira 343 (R!), syn. nov.

This species occurs in the Atlantic forest (MG) and in the Cerrado (GO and MG). It is submerged fixed, living in small rivers and streams. It was found in "Parque Estadual do Rio Preto" and "Parque Nacional da Serra do Cipó" conservation units. Because this species has a large extent of geographic occurrence, the conservation rating of Least Concern (LC) is proposed.

Eriocaulon aquatile can be recognized by: rhizome or short stem; membranaceous 3-5 nerved leaves; 1-3 scapes; staminate and pistillate flowers with sepals smaller than petals in mature capitula and staminate flowers with equal petals.

We compared the types as well as the data of the protologues of E. cipoense and E. aquatile, and found no morphological differences between these taxa. We also analyzed specimens from many localities in Minas Gerais, and all showed the same set of exclusive characters states, justifying the synonymy.

Eriocaulon angustifolium was considered a synonym of Eriocaulon aquatile Körn. by Giulietti (1978b). Nowadays, in the world checklist (Govaerts 2006), E. angustifolium is an accepted name but in the checklist of species from Brazil (Giulietti et al. 2013) it is considered a synonym of E. aquatile. According to the protologue of E. angustifolium, the type was collected in Minas Gerais, but on the type label at $\mathrm{K}$ is written "Goiás". This latter information can be corroborated by Gardner's manuscript: Catalogue of Brazilian Plants (Hind 2012), where the number 4382 was collected in Goiás. Images of the types indicate that E. angustifolium and E. aquatile seem to be distinct species. We also do not found E. aquatile from Goiás, in field work or herbaria specimens analyzed. However, the study of the types is necessary to know if $E$. angustifolium is really a synonym of E. aquatile or a distinct species. Therefore, we decide in this checklist, keep this binome as synonym of $E$. aquatile.

Selected material: BRAZIL. Minas Gerais, 11/VIII/2008, fl. fr., A. Oliveira \& R. Moura 91 (R).

3. Eriocaulon araguaiense A. Oliveira \& C. P. Bove, Syst. Bot. 36(3): 605. 2011. Type: BRAZIL. Mato Grosso: Cocalinho, 12/X/1997, C. P. Bove et al. 267 (R!).

This species occurs in the Cerrado (BA and MT). It is emergent, living on river banks. It was not found in conservation units. Because this species has a small area of occupancy $\left(<500 \mathrm{~km}^{2}\right)$, few locations are known $(\leq 5)$ and 
it suffers an increasing of human pressure with continuing decline of area of occupancy, the conservation rating of Endangered Category (ENB2) is proposed. Eriocaulon araguaiense was included in Critically Endangered category in the original description (Oliveira \& Bove 2011) but recent collections in western Bahia allow us to reclassify it.

Eriocaulon araguaiense can be recognized by: 1 nerved leaves; hemispherical capitula and obovate, olivaceous with cream-colored base involucral bracts.

Selected material: Bahia, Formoso do Rio Preto, rio Preto, $11^{\circ} 4^{\prime} 2.3^{\prime \prime}$ S, 45 19'12.8” W, 4/VI/2011, fl., C. P. Bove et al. 2265. (R).

4. Eriocaulon arechavaletae Herter, Revista Sudamer. Bot. 2: 125 (1935). Type: URUGUAY. José Arechavaleta 19 (?).

This species occurs in the Pampas (RS) and Uruguay. It was not found in conservation units. Because there is inadequate information to make a direct, or indirect, assessment of risk of extinction of this species, based on its distribution and/or population status, the conservation rating of Data Deficient (DD) is proposed.

The type has been not found, preventing a good characterization of this species.

5. Eriocaulon burchellii Ruhland, Pflanzenr. 4(30): 50. 1903. Type: BRAZIL. Goiás: Cavalcante, s.d., Burchell 7812 (B "photo!", NY "photo !").

This species occurs in the Cerrado (GO). It was not found in conservation units. Because this species has a small extent of geographic occurrence $\left(<100 \mathrm{~km}^{2}\right)$, only one location known, and it suffers an increasing of human pressure with continuing decline of area of occupancy, the conservation rating of Critically Endangered category (CRB1) is proposed.

Eriocaulon burchellii can be recognized by: lanceolate, 5-7 nerved leaves, smaller than spathe; hemispherical capitula; olivaceous involucral bracts; staminate flowers with ventral petal longer than the lateral ones.

6. Eriocaulon cabralense Silveira, Arq. Mus. Nac. Rio de Janeiro 23: 162. 1921. Type: BRAZIL. Minas Gerais: Serra do Cabral, VI/1910, A. Silveira 595 (R!).

Eriocaulon paludicola Silveira Arq. Mus. Nac. Rio de Janeiro 23: 162. 1921. Type: BRAZIL. Minas Gerais: Serra do Cabral, IV/1917, A. Silveira 553 (R!), syn. nov.

This species occurs in the Cerrado (MG). It is amphibious, living in temporarily flooded locations. It was found in "Parque Estadual da Serra do Cabral" conservation unit. This species has a small area of occupancy and few locations are known, but it does not suffer decline of extent of geographic occurrence, occupancy area or population. Because this, the conservation rating of Least Concern (LC) is proposed.
Eriocaulon cabralense can be recognized by: lanceolate leaves, longer than spathe; cylindrical capitula; staminate flowers with equal petals and anthophore pilose at lower part.

The protologues of E. cabralense and E. paludicola pointed out only one difference between these species: the receptacle is described as pilose to E. cabralense and glabrous to E. paludicola. They were described in the same article, probably collected close to each other. However, the types of these species were examined; and no differences were found, being here considered as synonyms.

7. Eriocaulon carajense Moldenke, Phytologia 27: 63. 1973. Type: BRAZIL. Pará: Marabá, 22/V/1969, P. Cavalcante 126 (LL "photo!").

This species occurs in the Amazon Forest (PA). It is amphibious, living in temporarily flooded locations in rupestrian ferruginous fields, locally known as "campo de canga". It was not found in conservation units. Because this species has a small extent of geographic occurrence $(<100$ $\mathrm{km}^{2}$ ), only one location known, and it suffers an increasing of human pressure with continuing decline of area of occupancy, the conservation rating of Critically Endangered category (CRB1) is proposed.

Eriocaulon carajense can be recognized by: lanceolate leaves, little longer or equal than spathe; hemispherical capitula; suborbiculate cream-colored involucral bracts and staminate flowers with obovate ventral petal.

8. Eriocaulon cinereum R. Br., Prodr. Fl. Nov. Holland. 254. 1810. Type: AUSTRALIA. s.d., J. Banks s.n. (?).

Eriocaulon damazianum Beauverd, Bull. Herb. Boissier 2(8): 986. 1908. Type: BRAZIL. Minas Gerais: Arraial Antônio Pereira, III/1907, L. Damazio 1944 (G “photo !", R!, RB!), syn. nov.

Eriocaulon longirostrum Silveira \& Ruhland, Pflanzenr. 4(30): 113. 1903. Type: BRAZIL. Minas Gerais: São João del Rei, VI/1986, A. Silveira 1268. (BHCB, NY “photo!”).

Eriocaulon sieboldianum Siebold \& Zucc. ex Steud., Syn. Pl. Glumac. 2: 272. 1855. Type: JAPAN. s.d., Siebold s.n. (?).

Eriocaulon steinbachii (Moldenke) Moldenke, Phytologia 2: 364. 1947. Type: BOLIVIA. Terebinto, 22/VIII/1916, J. Steinbach 2669 (LIL, NY "photo !").

This species is broadly distributed in America, Africa and Asia. In Brazil it occurs in the Cerrado (GO and MG). It is amphibious, living in temporarily flooded locations. It was found in "RPPN Santuário do Caraça" and "Parque Nacional da Chapada dos Veadeiros" conservation units. Because this species has broadly distribution with a large extent of geographic occurrence in Brazil, the conservation rating of Least Concern (LC) is proposed.

Eriocaulon cinereum can be recognized by: delicate habit; membranaceous leaves; trimerous flowers; staminate flowers with completely fused sepals and pistillate flowers with linear petals. 
This set of characters states is also found in Eriocaulon damazianum, supporting the inclusion of the latter as a synonym of E. cinereum.

9. Eriocaulon coniferum Herzog, Repert. Spec. Nov. Regni Veg. 20: 82. 1924. Type: BRAZIL. Bahia: Rio Grande, 1913, Luetzelburg 455 (F, M, R!).

This species occurs in the Cerrado (BA). It is amphibious, living in temporarily flooded locations. It was not found in conservation units. Because this species has a small extent of geographic occurrence $\left(<100 \mathrm{~km}^{2}\right)$, only one location known, and it suffers an increasing of human pressure with continuing decline of area of occupancy, the conservation rating of Critically Endangered category (CRB1) is proposed.

The type analyzed is a young specimen, preventing a good characterization of this species.

10. Eriocaulon crassiscapum Bong., Mém. Acad. Imp. Sci. St.-Pétersbourg, Sér. 6, Sci. Math. 1: 628. 1831. Type: BRAZIL. Minas Gerais: entre Prados e Barbacena, VI/18??, Riedel 296 (?).

Eriocaulon molle Mart., Fl. Bras. 3(1): 487. 1863. Type: BRAZIL. s.d., Martius 890 (MO “photo !").

This species occurs in the Atlantic Forest (MG and SP), Caatinga (BA) and Cerrado (MG and SP). It is amphibious, living in temporarily flooded locations. It was found in "Estação Experimental de Itapetininga" conservation unit. Because this species has a large extent of geographic occurrence, the conservation rating of Least Concern (LC) is proposed.

Eriocaulon crassiscapum can be recognized by: membranaceous leaves; hemispherical or ovoid capitula; incrassate scape and staminate flowers with ventral petal slightly longer than the lateral ones.

Selected material: BRAZIL. Minas Gerais: Ouro Preto, 4/ VIII/1968, fl., J. Badini et al. s.n. (OUPR 13375); Carandaí, 18/XI/1946, A. Duarte 514 (RB). São Paulo: Mogi Guaçu, s.d., Riedel 1481 (K). Santo Amaro, 24/ XII/1911, A. C. Brade 5536 (SP, SPF).

11. Eriocaulon cylindratum A. Oliveira \& C. P. Bove, Syst. Bot. 36(3): 605. 2011. Type: BRAZIL. Goiás: Aruanã, 11/XI/1999, C. P. Bove et al. 596 (R!).

This species occurs in the Cerrado (BA and GO). It is amphibious, living in temporarily flooded locations. It was not found in conservation units. Because this species has a small area of occupancy $\left(<500 \mathrm{~km}^{2}\right)$, few locations are known $(\leq 5)$ and it suffers an increasing of human pressure with continuing decline of area of occupancy, the conservation rating of Endangered Category (ENB2) is proposed. Eriocaulon cylindratum was included in Critically
Endangered category in the original description (Oliveira \& Bove 2011) but recent collections in western Bahia allow us to reclassify it.

Eriocaulon cylindratum can be recognized by: stoliniferous rhizome; 1 nerved leaves; cylindrical capitula and obtrullate involucral bracts.

Selected material: Bahia, Barreiras, 14/VII/1983, fl., L. S. S. Faria s.n. (HUEFS, SPF 65648).

12. Eriocaulon dictyophyllum Körn., Fl. Bras. 3(1): 486. 1863. Type: BRAZIL. São Paulo: Batatais, VI/1934, Riedel 2303 (B "photo !", F). Minas Gerais: "prope oppidum Salgado", s.d., Martius s.n. (?).

This species occurs in the Cerrado (MG and SP). It is amphibious, living in temporarily flooded locations. It was not found in conservation units. Because this species has a small area of occupancy $\left(<500 \mathrm{~km}^{2}\right)$, few locations are known $(\leq 5)$, and it suffers an increasing of human pressure with continuing decline of area of occupancy, the conservation rating of Endangered Category (ENB2) is proposed.

Eriocaulon dictyophyllum can be recognized by: membranaceous, 7-15 nerved leaves, little longer or equal than spathe, with disthicous alternate arrangement; hemispherical or ovoid capitula; cream-colored involucral bracts; olivaceous with cream colored base floral bracts and staminate flowers with ventral petal longer than the lateral ones.

Salgado is the ancient name of a villa, which in 1833 was declared the town of Januária (IBGE 2014a).

Selected material: BRAZIL. Minas Gerais: Paraopeba, s.d., fl., A. Silveira 467 (R).

\section{Eriocaulon dimerum (Giul. \& Miranda) A. Oliveira stat. nov.}

Eriocaulon ligulatum var. dimerum Giul. \& Miranda, Kew Bull. 64: 525-536. 2009. Type: BRAZIL. Bahia: Palmeiras, s.d., Giulietti et al. 781 (ALCB, CEPEC, HRB, HUEFS!, K).

This species occurs in the Caatinga (BA). It is amphibious, living in temporarily flooded locations. It was found in "APA Marimbus/Iraquara" conservation unit. This species has a small area of occupancy and few locations are known, but it does not suffer decline of extent occurrence, occupancy area or population. Because this, the conservation rating of Least Concern (LC) is proposed.

Eriocaulon ligulatum var. dimerum can be recognized by: robust habit; lanceolate, ca. 100 nerved and $2 \mathrm{~cm}$ wide leaves, longer than spathe; slit spathe with laciniate apex; hemispherical to spherical, compact capitula and dimerous flowers.

The stability and importance of these character states justify the elevation of E. ligulatum var. dimerum to species rank. Instead, Eriocaulon ligulatum (Vell.) L. B. Sm. has a closed spathe with truncate apex and trimerous flowers.

14. Eriocaulon elichrysoides Bong., Mém. Acad. Imp. Sci. 
St.-Pétersbourg, Sér. 6, Sci. Math. 1: 631. 1831. Type: BRAZIL. São Paulo: Rio Pardo, s.d., Riedel 480. (?).

Eriocaulon beauverdii Moldenke, Known Geogr. Distrib. Eriocaulac. 62. 1946. Type: BRAZIL. São Paulo, 5/X/1905, A. Usteri s.n. (?).

This species occurs in the Cerrado (MG) and Atlantic Forest (SP and PR). It is amphibious, living along river banks. It was found in the "Parque Nacional da Serra do Cipó" and "Parque Estadual da Serra do Mar" conservation units. Because this species has a large extent of geographic occurrence, the conservation rating of Least Concern (LC) is proposed.

Eriocaulon elichrysoides can be recognized by: robust habit; lanceolate, ca. 100 nerved and $2 \mathrm{~cm}$ wide, flat leaves, longer than spathe, with smooth transition from the sheath to the blade; closed spathe with truncate apex; hemispherical to spherical, compact capitula; cream-colored involucral bracts that surpass the diameter of capitula; oblong, cream-colored floral bracts with acuminate apex, giving an echinate aspect to the capitula and staminate flowers with equal petals.

Selected material: BRAZIL. Minas Gerais: Santana do Riacho, 17/VIII/2008, fl., A. Oliveira \& R. Moura 117 (R). São Paulo: São Paulo, 27/VII/1917, F. C. Hoehne 367 (SP).

15. Eriocaulon epapillosum Ruhland, Pflanzenr. 4(30): 57. 1903. Type: BRAZIL. Minas Gerais: Uberaba, VI/1892, E. Ule 3156 (B "photo !", F).

This species occurs in the Cerrado (MG). It was not found in conservation units. Because this species has a small extent of geographic occurrence $\left(<100 \mathrm{~km}^{2}\right)$, only one location known, and it suffers an increasing of human pressure with continuing decline of area of occupancy, the conservation rating of Critically Endangered category (CRB1) is proposed.

Eriocaulon epapillosum can be recognized by: lanceolate, 11-15 nerved leaves, equal or little longer than spathe; hemispherical capitula; olivaceous with cream-colored base floral bracts; staminate flowers with deeply concave sepals and equal petals.

\section{Eriocaulon gardnerianum (Körn.) A. Oliveira nom. nov. et stat. nov.}

Eriocaulon gibbosum var. longifolium Körn., Fl. Bras. 3(1): 489. 1863. Type: BRAZIL. Goiás, VI/1834, Gardner 4383 (B "photo !", K “photo !", P “photo !"). Minas Gerais: Uberaba, VI/1834, Riedel 2416 (B "photo !", K "photo !", P "photo !") Goiás: Salinas, V-VII/1844, Weddell 2128 (P "photo !"). Minas Gerais: Uberaba, s.d., Lund s.n. (P "photo!" [P01879402]). "in Brazilia orientali", s.d., Vauthier s.n. (?).
This species occurs in the Cerrado (BA, GO, MT, and $M G)$. It is emergent, living on river banks. It was not found in conservation units. Because this species has a large extent of geographic occurrence, the conservation rating of Least Concern (LC) is proposed.

Eriocaulon gardnerianum can be recognized by: membranaceous leaves, longer than spathe, in a spiral alternate arrangement; pistillate flowers with gibbous sepals, incrassate gibba and ventral petal slightly longer than the lateral ones.

Govaerts (2006) considered Eriocaulon gibbosum var. longifolium an accepted name; nonetheless Giulietti et al. (2013) synonymized it with Eriocaulon gibbosum. We consider that E. gibbosum var. longifolium has an exclusive and stable set of important characters states, presented above, against the incrassate leaves smaller than the spathe in a distichous alternate arrangement observed in E. gibbosum, justifying the elevation of this taxon to species rank.

Due to the previous existence of the binomium Eriocaulon longifolium the specific epithet "gardnerianum" was chosen in honor of the collector George Gardner (1812-1849†), a Scottish botanist and explorer who made important collections of the Brazilian flora (Stafleu \& Cowan 1976-1988).

Selected material: BRAZIL. Bahia: Correntina, 08/ VIII/1992, fl., M. A. Silva et al. 1593 (SP). Mato Grosso: $4 \mathrm{~km}$ de base camp $12^{\circ} 54^{\prime} \mathrm{S} 51^{\circ} 52^{\prime} \mathrm{W}, 11 / \mathrm{VI} / 1968$, Ratter et al. 1724 (UB).

17. Eriocaulon gibbosum Körn., Fl. Bras. 3(1): 489. 1863. Type: BRAZIL. Minas Gerais: Serra das Araras, 1840, Gardner 5275 (B "photo !", K “photo !”, NMNH, P "photo !', R!). Minas Gerais: Uberaba, s.d., Lund s.n. (?).

This species occurs in the Cerrado (MG). It was not found in conservation units. Because this species has a small extent of geographic occurrence $\left(<100 \mathrm{~km}^{2}\right)$, only one location known, and it suffers an increasing of human pressure with continuing decline of area of occupancy, the conservation rating of Critically Endangered category (CRB1) is proposed.

Eriocaulon gibbosum can be recognized by: incrassate leaves, smaller than spathe, with a distichous alternate arrangement; pistillate flowers with gibbous sepals; coriaceous gibba and ventral petal slightly longer than lateral petals.

18. Eriocaulon glaziovii Ruhland, Pflanzenr. 4(30): 51. 1903. Type: BRAZIL. Minas Gerais: rio Corumbá, s.d., A. Glaziou s.n. (B “photo!” [B100244420], F).

This species occurs in the Cerrado (MG). It is submerged fixed. It was not found in conservation units. Because this species has only one location known, and it suffers an increasing of human pressure with continuing decline of area of occupancy, the conservation rating of Critically Endangered category (CRB1) is proposed. 
Eriocaulon glaziovii can be recognized by: membranaceous, 8-15 nerved leaves; hemispherical capitula with vegetative reproduction; olivaceous with cream-colored base involucral bracts; olivaceous floral bracts; pistillate flowers with oblong to slightly obovate sepals and ventral petal slightly longer than the lateral ones.

19. Eriocaulon gomphrenoides Kunth, Enum. Pl. 3: 548. 1841. Type: BRAZIL. "Brasilia meridionalis", s.d., Sellow 3890 (B “photo !”, F, K “photo !”).

This species occurs in the "campos de altitude" (high-altitude grassland vegetation) of the Atlantic Forest (PR, RS, SC and SP). It is amphibious, living in temporarily flooded locations. It was found in the "Parque Nacional de São Joaquim" conservation unit. Because this species has a large extent of geographic occurrence, the conservation rating of Least Concern (LC) is proposed.

Eriocaulon gomphrenoides can be recognized by: robust habit; lanceolate, ca. 30 nerved and $0,5 \mathrm{~cm}$ wide leaves, longer than spathe, with distichous alternate arrangement; closed spathe with truncate apex; hemispherical to spherical, laxa capitula; cream-colored involucral bracts; sepals of staminate and pistillate flowers olivaceous.

Although the date on the type label is January 1836, Sellow died in 1831. The collection number indicates that this specimen was collected in Sellow's fourth expedition, from Montevideo, Uruguay to São Paulo, Brazil, between the years 1821-1829 (Moraes 2008).

Selected material: BRAZIL. Santa Catarina: Urubici, 8/XII/2000, fl., G. Hatschbach et al. 71670 (RB). São Paulo: Queluz, 22。 $24^{\prime} 30^{\prime \prime} \mathrm{S} 44^{\circ} 50^{\circ} 47^{\prime \prime} \mathrm{W}, \mathrm{II} / 1997$, fl., G. J. Shepherd et al. 97/14 (SP).

20. Eriocaulon griseum Körn., Fl. Bras. 3(1): 475. 1863. Type: BRAZIL. Piauí: inter Serra dos Dois Irmãos et Oeiras, V/1869, Martius s.n. (B "photo !” [B 100244413]).

This species occurs in the Caatinga and Cerrado (PI). It is amphibious, living in temporarily flooded locations. It was found in the "Parque Nacional da Serra das Confusões" conservation unit. This species has a small area of occupancy and few locations are known, but it does not suffer decline of extent of geographic occurrence, occupancy area or population. Because this, the conservation rating of Least Concern (LC) is proposed.

Eriocaulon griseum can be recognized by: delicate habit; membranaceous leaves; gray capitula; staminate flowers with completely fused sepals and pistillate flowers with petals similar to trichome.

Selected material: BRAZIL. Piauí: Caracol, 8/IV/2009, fl., G. Martinelli et al. 16307 (RB).

21. Eriocaulon guyanense Körn., Fl. Bras. 3(1): 478. 1863. Type: GUYANA. Herb. Paris 173 (B "photo !"). GUYANA. Herb. Paris 125 (?).
Eriocaulon stramineum Körn., Fl. Bras. 3(1): 478. 1863. Type: BRAZIL. Goiás: Salinas, s.d., Weddell 2130 (P “photo!”).

This species occurs in the Amazon Forest (AM, MA, and $\mathrm{PA}$ ), Cerrado (GO and MT) and Guyana. It is amphibious, living in temporarily flooded locations. It was collected in the "Parque Nacional da Chapada dos Veadeiros" conservation unit. Because this species has a large extent of geographic occurrence, the conservation rating of Least Concern (LC) is proposed.

Eriocaulon guyanense can be recognized by: delicate habit; membranaceous leaves, smaller than or equal the spathe; light cream-colored, hemispherical or ovoid capitula; dimerous flowers and pistillate flowers with widely ovate, winged sepals.

Selected material: BRAZIL. Goiás: Vila de São Jorge, 05/ VII/2009, fl., A. Oliveira et al. 245a (R). Maranhão: Carolina, 01/VI/1930, fl., J. M. Pires \& Black 2538 (INPA).

22. Eriocaulon herzogii Moldenke, Phytologia 19: 44. 1969. Eriocaulon pterosepalum Herzog, Repert. Spec. Nov. Regni Veg. 29: 204. 1931. Type: BRAZIL. Pará (?): Teju, IX/1927, Luetzelburg 21052 (R!, NY “photo !”). Pará (?): Milho, s.d., Luetzelburg 21053 (NY "photo !") nom. illeg.

This species occurs in the Amazon Forest (MA or PA). It is amphibious, living in temporarily flooded locations. It was not found in conservation units. Because this species has a small extent of geographic occurrence $\left(<100 \mathrm{~km}^{2}\right)$, only one location known, and it suffers an increasing of human pressure with continuing decline of area of occupancy, the conservation rating of Critically Endangered category (CRB1) is proposed.

Eriocaulon herzogii can be recognized by: delicate habit; lanceolate, 5-7 nerved leaves; hemispherical capitula; creamcolored involucral bracts; trimerous flowers; staminate flowers with crenate sepals; pistillate flowers with winged sepals and barbate apex.

The voucher Luetzelburg 21052 was collected in "Nordbrasilien, Staat Pará (?): Teju, feuchte Campos, fast im Wasser". This is probably the village of Santa Maria de Teju in Viana Municipality, Maranhão.

23. Eriocaulon humboldtii Kunth, Enum. pl. 3: 544. 1841. Type: VENEZUELA. s.d., Humboldt s.n. (B "photo !" [Macbride photo10560]).

Eriocaulon aequinoctiale Ruhland, Pflanzenr. 4(30): 47. 1903. Type: VENEZUELA. Tiramuto, s.d., Passarge \& Selwyn 590 (?).

This species occurs in Brazil, in the Amazon Forest (AC, AP, PA, RR, and TO), and the Cerrado (MT and MS) as well in Venezuela. It is amphibious, living in temporarily flooded locations. It was found in "Reserva do Cabaçal" conservation unit. Because this species has a large extent 
of geographic occurrence, the conservation rating of Least Concern (LC) is proposed.

Eriocaulon humboldtii can be recognized by: robust habit; chartaceous leaves, longer than or equal to sphate; hemispherical, compact, 1-3 capitula and staminate flowers with ventral petal longer than the lateral ones.

Selected material: BRAZIL. Mato Grosso do Sul: Sonora, 22/VII/2003, fl., C. P. Bove et al. 1154 (R). Roraima: Boa Vista, 03/XI/1977, fl., L. Coradin \& M. R. Cordeiro s.n. (INPA 76286).

24. Eriocaulon koernickei Britton, J. Bot. 38: 482. 1900.

Eriocaulon pygmaeum Körn., Fl. Bras. 3(1): 477. 1863. Type: "Brasilia orientali", s.d. Vauthier s.n. (B "photo !"). nom. illeg.

Eriocaulon vauthieri (Körn.) Ruhland, Pflanzenr. (4)30: 37. 1903.

The domain where this species occurs is unknown. It was not found in conservation units. Because there is inadequate information to make a direct, or indirect, assessment of risk of extinction of this species, based on its distribution and/or population status, the conservation rating of Data Deficient (DD) is proposed.

Eriocaulon koernickei can be recognized by: delicate habit; membranaceous leaves, much longer than the spathe; cream-colored, hemispherical or ovoid capitula; dimerous flowers and pistillate flowers with widely ovate, winged sepals.

It is very similar to and may be a synonym of Eriocaulon guyanense, although a more detailed analysis of types is needed to resolve this question.

25. Eriocaulon laxifolium Körn., Fl. bras. 3(1): 4941863. Type: BRAZIL. Minas Gerais, s.d., Martius s.n. (F).

This species occurs in the Cerrado (MG). It was not found in conservation units. Because this species has only one location known, and it suffers an increasing of human pressure with continuing decline of area of occupancy, the conservation rating of Critically Endangered category (CRB1) is proposed.

Eriocaulon laxifolium can be recognized by: robust habit; lanceolate, membranaceous leaves, longer than sphate; hemispherical and compact capitula; olivaceous involucral bracts and staminate flowers with equal petals.

26. Eriocaulon leptophyllum Kunth, Enum. Pl. 3: 549. 1841. Type: BRAZIL. Rio Grande do Sul, s.d., Sellow d2513 (B "photo!", K "photo !").

This species occurs in the Pampas (RS) and Uruguay. It is submerged fixed, living in temporarily flooded locations. It was not found in conservation units. Because this species has only one location known, and it suffers an increasing of human pressure with continuing decline of area of occupancy, the conservation rating of Critically Endangered category (CRB1) is proposed.

Eriocaulon leptophyllum can be recognized by: membranaceous leaves, longer than spathe; hemispherical capitula; olivaceous with cream-colored base involucral bracts; staminate flowers with completely fused sepals and ventral petal slightly longer than lateral petals.

On the type label $(\mathrm{K})$ is written "Brasilia meridionalis", December 1836. Nonetheless, Sellow died in 1831 (Moraes 2008). Numbers d2439-2818 were collected in Porto Alegre and Serra do Herval from January to September 1825 (Urban 1906).

27. Eriocaulon ligulatum (Vell.) L. B. Sm., Contr. Gray Herb. 124: 5 1939. Type: plate published in Flora fluminensis vol 1. tab. 86. 1827.

Dupatya ligulata Vell., Fl. flumin. vol 1. tab. 86. 1827.

Eriocaulon kunthii Körn., Fl. Bras. 3(1): 482-483. 1863. Type: BRAZIL. São Paulo: Rio das Pedras, s.d., Sellow 1290 (B "photo !"). Minas Gerais: Congonhas do Campo, s.d., Stephan s.n. (NY “photo !”). São Paulo, s.d., Riedel 2388 (?)

Eriocaulon magnificum var. goyazense Moldenke, Phytologia 18: 342. 1969. Type: BRAZIL. Goiás: rodovia Brasilia - Belo Horizonte, divisa do DF, 8/VIII/1968, E. P. Heringer \& N. Lima 11717 (NY “photo!", UB!), syn. nov.

Eriocaulon vaginatum Körn., Fl. Bras. 3(1): 483-484. 1863. Type: BRAZIL. Minas Gerais: Caldas, s.d. Regell. s.n. (B "photo !") syn. nov.

This species occurs in the Caatinga (BA), Cerrado (GO, MG, SP, and DF) and Atlantic Forest (RJ). It is amphibious, living in temporarily flooded locations and river banks. It was found in "RPPN Santuário do Caraça" conservation unit. Because this species has a large extent of geographic occurrence, the conservation rating of Least Concern (LC) is proposed.

Eriocaulon ligulatum can be recognized by: robust habit; lanceolate, ca. 100 nerved and $2 \mathrm{~cm}$ wide, plicate leaves, longer than spathe, with abrupt transition to sheath from blade; closed spathe with truncate apex; hemispherical to spherical, compact capitula; oblong, cream-colored floral bracts with acute or acuminate apex; staminate flowers with equal petals.

We noted that specimens under the name of Eriocaulon magnificum var. goyazense have the same exclusive set of characters states of E. ligulatum whereas E. magnificum var. magnificum Ruhland has a slit spathe with acute apex, justifying the synonymy. Eriocaulon vaginatum also, has the same exclusive set of characters states being here considered a synonym of Eriocaulon ligulatum.

Selected material: BRAZIL. Bahia: Caetité, 13/IV/1980, fl., R. M. Harley 21342 (HUEFS). Minas Gerais, 31/ VIII/1986, fl., J. Badini s.n. (OUPR 13111, R). 
28. Eriocaulon linearifolium Körn., Linnaea 27: 601. 1854. Type: BRAZIL. Pernambuco: Rio Preto, IX/1839, Gardner 2954 (B “photo !", F, G "photo !", K “photo !”).

This species occurs in the Atlantic Forest (PE). It is amphibious, living in temporarily flooded locations. It was not found in conservation units. Because this species has only one location known, and it suffers an increasing of human pressure with continuing decline of area of occupancy, the conservation rating of Critically Endangered category (CRB1) is proposed.

Eriocaulon linearifolium can be recognized by: robust habit; linear leaves, longer than or equal to sphate; hemispherical and compact capitula; staminate flowers with equal petals and white anthers.

The locality on the type label at B and G herbaria as well in the protologue is "Piahui", while on the the type label at $\mathrm{K}$ herbarium is printed "Bahia, Serra da Batalha", but also is written, in ink, "Pernambuco, Rio Preto". This latter information can be corroborated by Gardner's manuscript: Catalogue of Brazilian Plants (Hind 2012), where the number 2954 was collected in Pernambuco. The Rio Preto is a tributary of Rio Una, located between the towns of Palmeiras and Água Preta (IBGE 2014b).

29. Eriocaulon macrobolax Körn., Fl. Bras. 3(1): 484. 1863. Type: BRAZIL. Minas Gerais, s.d., Martius s.n. (B "photo !" - fragm. [B100244405], F).

This species occurs in the Cerrado and Atlantic Forest (MG), in dry or moist habitats. It was not found in conservation units. Because there is inadequate information to make a direct, or indirect, assessment of risk of extinction of this species, based on its distribution and/or population status, the conservation rating of Data Deficient (DD) is proposed.

The type has only one leaf preventing a good characterization of this species.

The protologue mentions two localities in Minas Gerais: an unknown place on the bank of São Francisco River and the Serra de Santo Antônio, located in southern Minas Gerais, near Andrelândia.

30. Eriocaulon magnificum Ruhland, Pflanzenr. 4(30): 48 1903. Type: BRAZIL. Santa Catarina: Tubarão, IX/1890, E. Ule 1689 (B “photo !", F, HBG "photo !").

Eriocaulon deslandesii Silveira, Floral. Mont. 1: 421422. 1928. Type: BRAZIL. Rio Grande do Sul: Povo Novo, X/1928, A. Silveira 220 (R!).

Eriocaulon reitzii Moldenke \& L. B. Sm., Phytologia 25: 430. 1973. Type: BRAZIL. Santa Catarina: São José, 24/X/1954, R. Reitz \& R. M. Klein 5428 (NMNH, US "photo !"), syn. nov.

This species occurs in the Atlantic Forest (SC) in Restinga vegetation, and in the Pampas (RS). It is amphibious, living in temporarily flooded locations. It was not found in conservation units. Because this species has a small extent of geographic occurrence $\left(<20,000 \mathrm{~km}^{2}\right)$, with few locations known $(\leq 10)$, and it suffers an increasing of human pressure with continuing decline of area of occupancy, the conservation rating of Vunerable (VUB1) is proposed.

Eriocaulon magnificum can be recognized by: robust habit; lanceolate, ca. 100 nerved and $2 \mathrm{~cm}$ wide, plicate leaves, longer than spathe, with abrupt transition to sheath from blade and distichous alternate arrangement; slit spathe with acute apex; hemispherical to spherical, compact capitula; cream-colored floral bracts; staminate flowers with equal petals; pistillate flowers inserted in a long, villous anthophore, $2.5 \times 1 \mathrm{~mm}$ and ventral petal longer than the lateral petals.

The protologue of Eriocaulon reitzii mentioned the similarity with Eriocaulon magnificum, but no distinctive features were stated. We noted that this species has the same exclusive set of characters states presented above. Because this, Eriocaulon reitzii is here considered as a synonym of E. magnificum.

Selected material: BRAZIL. Rio Grande do Sul: Povo Novo, X/1928, fl., A. Silveira 220 (R!).

31. Eriocaulon magnum Abbiatti, Revista Mus. La Plata, Secc. Bot.6(26): 323. 1946. Type: ARGENTINA. Chaco, X/1945, A. G. Schultz 6337 (LP).

Eriocaulon singulare Moldenke, Phytologia 48: 253. 1981. Type: BRAZIL. Minas Gerais: Ituiutaba, 16/IX/1950, A. Macedo 2589 (NY “photo!”), syn. nov.

This species occurs in the Cerrado (MG and SP), in the "campos de altitude" (high-altitude grassland vegetation) of the Atlantic Forest (PR, SC, and SP) and in the Pampas (RS), Argentina, and Paraguay. It is amphibious, living in temporarily flooded locations or in floating mats in lakes. It was found in "APA Rio Vermelho/Humbold" and "APA Estadual de Guaratuba" conservation units. Because this species has a large extent of geographic occurrence, the conservation rating of Least Concern (LC) is proposed.

Eriocaulon magnum can be recognized by: robust habit; lanceolate, ca. 100 nerved and $2 \mathrm{~cm}$ wide, plicate leaves, longer than spathe, with abrupt transition to sheath from blade and disthicous alternate arrangement; closed spathe with obtuse apex and composed (with two or three capitula), hemispherical to spherical, compact capitula.

Eriocaulon magnum was described from Argentina and Paraguay, and Eriocaulon singulare from Brazil (state of Minas Gerais). Both have the same exclusive set of characters states. Analysis of specimens from Argentina, Paraguay and Brazil (states of Minas Gerais, Paraná and Rio Grande do Sul) showed no morphological distinctions and a continuous geographic distribution; therefore, E. singulare is considered here as a synonym of E. magnum.

The type locality cited in the protologue of Eriocaulon singulare is "from campestre do brejo, La Serra do Conego, 
Minas Gerais, Brazil". However, on the type label there is no mention of the Serra do Conego. We suppose that this is a misspelling of beira do córrego, which means creek bank. Moreover, the type label also bears the word Ituiutaba, the town where the type was collected.

Selected material: BRAZIL. Paraná: Curitiba, 8/IX/1966, fl., J. C. Lindeman \& J. H. Haas 2419 (RB). São Paulo: Bauru, 12/VII/1986, fl., A. D. Faria et al. 96/211 (SPF). Cubatão, VII/1986, fl., M. Sugiyama \& M. Kirizawa 666 (SP). ARGENTINA. Corrientes, 26/IX/2007, fl., Schinini et al. 36862 (HUEFS).

32. Eriocaulon majusculum Ruhland, Pflanzenr. 4(30): 45. 1903. Type: BRAZIL. Rio de Janeiro: Serra do Itatiaia, XII/1895, E. Ule 3770 (B “photo !", HBG “photo !").

This species occurs in "campos de altitude" (high-altitude grassland vegetation), in the Atlantic Forest (MG and RJ). It is emergent, living in flooded locations. It was found in the "Parque Nacional do Itatiaia" conservation unit. Because this species has a large extent of geographic occurrence, the conservation rating of Least Concern (LC) is proposed.

Eriocaulon majusculum can be recognized by: robust habit; lanceolate, ca. 100 nerved and $1 \mathrm{~cm}$ wide leaves, longer than spathe, with spiral alternate arrangement; closed spathe with truncate apex; hemispherical to spherical, compact capitula and ovate, cream-colored floral bracts with acute apex.

Selected material: BRAZIL. Rio de Janeiro: planalto do Itatiaia, 22-28/XI/1938, fl., fr., Markgraf \& Brade 3661 (RB).

33. Eriocaulon megapotamicum Malme, Ark. Bot. $26 \mathrm{~A}(9)$ : 8. 1935. Type: BRAZIL. Rio Grande do Sul: Povo Novo, 12/ XI/1901, Malme II:406 (S “photo !") .

This species occurs in the Pampas (RS). It is amphibious, living in temporarily flooded locations. It was not found in conservation units. Because this species has a small extent of geographic occurrence $\left(<5,000 \mathrm{~km}^{2}\right)$, with few locations known $(\leq 5)$, and it suffers an increasing of human pressure with continuing decline of area of occupancy, the conservation rating of Endangered (ENB1) is proposed.

Eriocaulon megapotamicum can be recognized by: robust habit; lanceolate, ca. 100 nerved and $2 \mathrm{~cm}$ wide, plicate leaves, longer than spathe, with distichous alternate arrangement; slit spathe with laciniate apex; hemispherical to spherical, laxa capitula; oblong, olivaceous floral bracts and pistillate flowers, inserted in a long anthophore, with villous petals.

34. Eriocaulon melanolepis Silveira, Arq. Mus. Nac. Rio de Janeiro 23: 163. 1921. Type: BRAZIL. Minas Gerais: Sete Lagoas, IV/1908, Serra do Cabral, VI/1910, A. Silveira 500 (R!).

This species occurs in the Cerrado (MG). It is submerged fixed, living in rivers. It was not collected in conservation units. Because this species has a small area of occupancy $\left(<500 \mathrm{~km}^{2}\right)$, few locations are known $(\leq 5)$ and it suffers an increasing of human pressure with continuing decline of area of occupancy, the conservation rating of Endangered Category (ENB2) is proposed.

Eriocaulon melanolepis can be recognized by: linear, 6-7 nerved leaves; olivaceous involucral bracts; hemispherical, ca. 10 capitula; trimerous flowers and staminate flowers with the ventral petal longer than the lateral ones

Selected material: BRAZIL. Minas Gerais: Lagoa Santa, 04/VII/1936, fl., Mello Barreto 4406 (R).

35. Eriocaulon milhoense Herzog, Repert. Spec. Nov. Regni Veg. 29: 204. 1931. Type: BRAZIL. Pará (?): Milho, s.d., Luetzelburg 21053b (F, M).

This species occurs in the Amazon Forest (MA or PA). It is amphibious, living in temporarily flooded locations. It was not found in conservation units. Because this species has a small extent of geographic occurrence $\left(<100 \mathrm{~km}^{2}\right)$, only one location known, and it suffers an increasing of human pressure with continuing decline of area of occupancy, the conservation rating of Critically Endangered category (CRB1) is proposed.

Eriocaulon milhoense can be recognized by: delicate habit; lanceolate, 5-7 nerved leaves; hemispherical capitula; involucral bracts cream-colored; trimerous flowers; staminate flowers with crenate sepals; pistillate flowers with winged sepals and barbate apex.

Although no information on the locality mentioned in the protologue (Milho) was found, according to the data from the preceding collection numbers of Luetzelburg (21052 and 21053a), the type was collected near the village of Santa Maria de Teju in Viana Municipality, Maranhão.

36. Eriocaulon modestum Kunth, Enum. pl. 547. 1841. Type: BRAZIL. Santa Catarina, s.d., Gaudichaud 1835 (B "photo !"). Rio de Janeiro: Praia de Sernambetiba, s.d., Luschnath s.n. (?).

Eriocaulon modestum $\mathrm{f}$. viviparum Herzog ex Moldenke, Phytologia 25(7): 432. 1973. Type: BRAZIL. Goiás, 1913, Luetzelburg 15510 (NY "photo !").

Eriocaulon candidum Moldenke, Bull. Torrey Bot. Club 77: 389. 1950. Type: BRAZIL. Rio Grande do Sul: Tramandaí, 30/X/1949, A. R. Schultz 700 (NY“photo !"), syn. nov.

Eriocaulon steyermarkii var. bahiense Moldenke, Phytologia 31: 229. 1975. Type: BRAZIL. Bahia: $5 \mathrm{~km}$ W of Mucugê, Fazenda Paraguaçú, $41^{\circ} 25^{\prime}$ W, $13^{\circ} 02^{\prime}$ S, 6/II/1974, R. M. Harley et al. 16068 (LL "photo !", MO "photo !", K "photo !"), syn. nov.

This taxon occurs in the Caatinga (BA and PI), Cerrado (GO, MG, MT, and DF), Atlantic Forest (PR, RJ, RS, SC, and $\mathrm{SP}$ ), and Pampas (RS). It is submerged fixed, living in permanently flooded locations or small rivers. It was found in the "Parque Nacional da Chapada dos Veadeiros" and "Parque Nacional da Chapada Diamantina" conservation units. Be- 
cause this species has a large extent of geographic occurrence, the conservation rating of Least Concern (LC) is proposed.

Eriocaulon modestum can be recognized by: fenestrate leaves, longer or equal than spathe; floral bracts with creamcolored base and olivaceous apex; trimerous flowers; staminate flowers with the frontal petal much longer than the lateral ones. However, it has variable morphology in some respects: the involucral bracts can be ovate to obovate, and the floral bracts can be oblong to obtrullate with olivaceous to cream-colored base. The presence of viviparous capitula can be observed in some populations collected in Goiás.

Eriocaulon candidum shows the exclusive set of characters states presented above, therefore, is considered here as a synonym of $E$. modestum.

Eriocaulon steyermarkii var. bahiensis has been distinguished from the typical variety, in the protologue, by its brownish involucral bracts with acute apex, against black involucral bracts with obtuse apex. However, after analysis of the protologue of Eriocaulon steyermarkii var. bahiensis, images of the type, as well a specimen collected in the type locality (A. Oliveira \& R. Moura 192 (R)) we realize that the set of characters of E. steyermarkii var. bahiensis is consistent with that found in Eriocaulon modestum. Eriocaulon steyermarkii Moldenke var. steyermarkii has dimerous flowers and the staminate flowers with equal petals whereas Eriocaulon steyermarkii var. bahiensis has the same set of states of characters, presented above. The stability and importance of them indicate that this taxon is not a variety of Eriocaulon steyermarkii but a synonym of E. modestum. We also should consider the great geographic disjunction of these taxa. While Eriocaulon steyermarkii var. bahiensis occurs in the Caatinga in state of Bahia in Brazil Eriocaulon steyermarkii Moldenke var. steyermarkii occurs in Amazon Forest in Venezuela, Guyana, and Suriname.

Selected material: BRAZIL. Goiás: Alto Paraíso de Goiás, 02/VI/2009, fl., A. Oliveira et al. 233 (R). Rio Grande do Sul: Tramandaí, IX/1973, fl., fr., J. Vidal. IV-174 (R).

\section{Eriocaulon multiscapum (Moldenke) A. Oliveira nom. nov. et stat. nov.}

Eriocaulon aquatile var. latifolium Moldenke, Phytologia 48(3): 253. 1981. Type: BRAZIL. Amapá: acampamento Henrique BR 156, 11/II/1979, B. Rabelo 6 (NY “photo !”).

This species occurs in the Amazon Forest (AP and PA). It is submerged fixed, living in streams. It was not found in conservation units. Because this species has a large extent of occurrence, a conservation rating of Least Concern (LC) is proposed.

Eriocaulon aquatile var. latifolium can be recognized by: mebranaceous, ca. 40 nerved leaves; ca. 100 scapes; hemispherical capitula and staminate flowers with equal petals.

Although Eriocaulon aquatile var. latifolium is currently considered a synonym of Eriocaulon aquatile var. aquatile (Govaerts 2006, Giulietti et al. 2013), this variety has an exclusive set of characters states, presented above whereas the tipical variety has 3-5 nerved leaves and 1-3 capitula. We also should consider the great geographic disjunction of these taxa. Eriocaulon aquatile var. latifolium occurs in the Amazon forest, in the state of Amapá while Eriocaulon aquatile var. aquatile occurs in the Cerrado, only in the state of Minas Gerais. The stability and importance of these character states as well the geographic disjunction justify the elevation of E. aquatile var. latifolium to species rank.

Because the binomen Eriocaulon latifolium $\mathrm{Sm}$. is preoccupied, the specific epithet "multiscapum" was chosen in reference to the large number of scapes.

Selected material: BRAZIL. Amapá: Amapá, 22/IX/2014, fl., C. P. Bove \& C. T. Philbrick 2470 (R).

38. Eriocaulon neglectum Ruhland, Pflanzenr. 4(30): 59 1903. Type: BRAZIL. Goiás, s.d., Gardner 4381 (B "photo !", K "photo !", W).

This species occurs in the Cerrado (GO). The life form and habitat are unknow. It was not found in conservation units. Because this species has only one location known, and it suffers an increasing of human pressure with continuing decline of area of occupancy, the conservation rating of Critically Endangered category (CRB1) is proposed.

Eriocaulon neglectum can be recognized by: delicate habit; lanceolate, membranaceous, 3-4 nerved leaves, longer than or equal the spathe; hemispherical, laxa, gray capitula; olivaceous with cream-colored base floral sepals, longer than flowers and trimerous flowers.

39. Eriocaulon obtusum Ruhland, Pflanzenr. 4(30): 46. 1903. Type: BRAZIL. Minas Gerais: Uberaba, VI/1892, E. Ule 3157 (B“"photo !").

This species occurs in the Cerrado (MG). It is amphibious, living in temporarily flooded locations. It was not found in conservation units. Because this species has a small extent of geographic occurrence $\left(<100 \mathrm{~km}^{2}\right)$, only one location known, and it suffers an increasing of human pressure with continuing decline of area of occupancy, the conservation rating of Critically Endangered category (CRB1) is proposed.

Eriocaulon obtusum can be recognized by: incrassate leaves, much smaller than spathe; hemispherical capitula; floral bracts cream-colored and staminate flowers with ventral petal slightly longer than the lateral ones.

Selected material: BRAZIL. Minas Gerais: Uberaba, 04/ VII/1936, fl., Mello Barreto 4406 (HUFU).

40. Eriocaulon palustre Salzm. ex Steud, Syn. Pl. Glumac. 2(10): 280. 1855. Type: BRAZIL. Bahia, s.d., P. Salzmann s.n. (G “photo !", K "photo !", MO "photo !" [2133721]).

This species occurs in the Atlantic Forest, in Restinga vegetation (BA and $\mathrm{PE}$ ). It is emergent, living in temporarily 
flooded locations. Because this species has a small area of occupancy $\left(<500 \mathrm{~km}^{2}\right)$, few locations are known $(\leq 5)$ and it suffers an increasing of human pressure with continuing decline of area of occupancy, the conservation rating of Endangered Category (ENB2) is proposed.

Eriocaulon palustre can be recognized by: delicate habit; membranaceous leaves, longer than spathe; gray capitula; pistillate flowers with sepals completely fused and incrassate petals.

Selected material: BRAZIL. Bahia: Canavieiras, 12/ VI/1978, fl., fr., T. S. dos Santos \& L. A. Mattos-Silva s.n. (HUEFS 38841).

41. Eriocaulon papillosum Körn., Fl. Bras. 3(1): 489. 1863. Type: BRAZIL. Goiás, s.d., Weddell 2135 (NY "photo !" - fragm., P "photo !").

This species occurs in the Cerrado (GO). It is amphibious, living in temporarily flooded locations. It was not found in conservation units. Because this species has a small area of occupancy $\left(<500 \mathrm{~km}^{2}\right)$, few locations are known $(\leq 5)$ and it suffers an increasing of human pressure with continuing decline of area of occupancy, the conservation rating of Endangered Category (ENB2) is proposed.

Eriocaulon papillosum can be recognized by: papillose leaves, smaller than spathe; hemispherical or cylindrical capitula; cream-colored floral bracts and staminate flowers with petals slightly longer than the lateral ones.

Selected material: BRAZIL. Tocantins: Almas, 06/ VI/2009, fl., fr., A. Oliveira et al. 255 (R).

42. Eriocaulon paraguayense Körn., Fl. Bras. 3(1): 497. 1863. Type: BRAZIL. Mato Grosso: Rio Paraguai, s.d., Weddell 3054 (NY “photo !" - fragm., P "photo !").

This species occurs in the Cerrado (MT). It was not found in conservation units. Because this species has only one location known, and it suffers an increasing of human pressure with continuing decline of area of occupancy, the conservation rating of Critically Endangered category (CRB1) is proposed.

It is very similar to and may be a synonym of Eriocaulon humboldtii, although a more detailed analysis of types is needed to resolve this question.

43. Eriocaulon pilgeri Ruhland, Bot. Jahrb. Syst. 30(2): 147. 1901. Type: BRAZIL. Mato Grosso, 24/II/1899, Pilger 239 (B "photo !").

This species occurs in the Cerrado (MT). It is amphibious, living in temporarily flooded locations. It was not found in conservation units. Because this species has a small area of occupancy $\left(<500 \mathrm{~km}^{2}\right)$, few locations are known $(\leq 5)$ and it suffers an increasing of human pressure with continuing decline of area of occupancy, the conservation rating of Endangered Category (ENB2) is proposed.

Eriocaulon pilgeri can be recognized by: lanceolate leaves, smaller than spathe; hemispherical or cylindri- cal capitula; obtrullate, cream-colored floral bracts with acuminate apex; pistillate flowers with gibbous sepals and membranaceous gibba.

Ruhland (1901) mentioned the similarity between $E$. gibbosum and E. pilgeri, but without seeing the pistillate flowers of the latter. Eriocaulon pilgeri has the characters states presented above whereas E. gibbosum has obovate, olivaceous with cream-colored base floral bracts with acute apex; pistillate flowers with gibbous sepals and coriaceous gibba.

Selected material: BRAZIL. Mato Grosso: Cuiabá, 26/ IV/1964, fl., G. Malme 1572 (R!, F, NY “photo !”).

44. Eriocaulon radiosum (Ruhland) A. Oliveira, stat. nov. Eriocaulon ulaei var. radiosa Ruhland, Pflanzenr. 4(30): 48. 1903. Type: BRAZIL. Santa Catarina: "Insel Sa Catharina”, II/1887, E. Ule 639 (B “photo !").

This species occurs in the Atlantic Forest, in Restinga vegetation (SC). It is amphibious, living along lakeshores. It was not found in conservation units. Because this species has a small extent of geographic occurrence $\left(<100 \mathrm{~km}^{2}\right)$, only one location known, and it suffers an increasing of human pressure with continuing decline of area of occupancy, the conservation rating of Critically Endangered category (CRB1) is proposed.

Eriocaulon radiosum can be recognized by: robust habit; lanceolate, chartaceous, ca. 100 nerved leaves, longer than spathe, with disthicous alternate arrangement; slit spathe with acuminate apex; hemispherical capitula; often viviparous; narrowly involucral bracts and reflexed floral bracts surpassing the capitula.

Eriocaulon ulaei var. radiosa was distinguished from Eriocaulon ulaei Ruhland var. ulaei in the protologue by the often viviparous capitula and the narrowly involucral bracts. However, the outstanding character in this taxon is the presence of reflexed floral bracts surpassing the capitula. These character states, together with the sheath with a lateral slit and the acuminate apex, provide this taxon an exclusive and stable set of characters states, justifying its elevation to species rank.

45. Eriocaulon regnellii Moldenke, Phytologia 3: 35. 1948. Type: BRAZIL. Minas Gerais: Caldas, 20/IV/1870, A. F. Regnell III.1740 (NY "photo !").

This species occurs in the Atlantic Forest (MG). It was found in "APA Sul RMBH" conservation unit. This species has a small area of occupancy and few locations are known, but it does not suffer decline of extent occurrence, occupancy area or population. Because this, the conservation rating of Least Concern (LC) is proposed.

It is very similar to and may be a synonym of Eriocaulon neglectum, although a more detailed analysis of types is needed to resolve this question. 
46. Eriocaulon sellowianum Kunth, Enum. pl. 545. 1841. Type: BRAZIL. s.d., Sellow s.n. (B “photo !” [B100244385]).

Eriocaulon sellowianum var. minor Moldenke, Phytologia 26: 463. 1973. Type: BRAZIL. Goiás: Chapada dos Veadeiros, Harley et al. 11388 (K "photo !"), syn. nov.

Eriocaulon sellowianum var. paranense (Moldenke) Moldenke \& L. B. Sm., Phytologia 26: 37. 1973. Type: BRAZIL. Paraná, 5/XII/1981, L. B. Smith et al. 15667 (K "photo!"), syn. nov.

Eriocaulon rosulatum Körn., Fl. Bras. 3(1): 487. 1863. Type: BRAZIL. Minas Gerais: "prope Salgado", s.d., Martius s.n. (F, M "photo !"), syn. nov.

This species occurs in Brazil and Paraguay. In Brazil it occurs in the Atlantic Forest (BA, MG, PR, and SC) and in the Cerrado (GO, MG, MT, MS, SP, and DF). It is amphibious, living in temporarily flooded locations. It was found in the "Parque Nacional da Chapada dos Veadeiros" conservation unit. Because this species has a large extent of geographic occurrence, the conservation rating of Least Concern (LC) is proposed.

Eriocaulon sellowianum can be recognized by: incrassate leaves, much smaller than spathe; hemispherical capitula; floral bracts cream-colored and staminate flowers with ventral petal longer than the lateral ones.

Eriocaulon sellowianum var. minor has been distinguished from the typical variety only by the smaller size. Analyses of 32 collections from many localities distributed in all domains where this species occurs showed a highly variable size in different populations, as well as in the same population. Likewise, there are no distinctive characters between Eriocaulon sellowianum var. paranense, Eriocaulon rosulatum and Eriocaulon sellowianum.

Selected material: BRAZIL. Minas Gerais: Carandaí, 28/ XI/1946, fl., A. P. Duarte 679 (RB). Paraná: Ponta Grossa, XII/1969, fl., fr., L. Krieger 7540 (CESJ). São Paulo: Itararé, 30/X/1993, fl., V. C. Souza et al. 4395 (SPF).

47. Eriocaulon setaceum L., Sp. pl. 1: 87. 1753. Type: Sri Lanka, Herb. Hermann species n. 50 (BM).

Eriocaulon capillus-naiadis Hook. f., Fl. Brit. India 6: 572. 1893. Type: INDIA. Khasia Hills, s.d., J. D. Hooker \& T. Thomson s.n. (CAL "photo !" [CAL0000001691]).

Eriocaulon heteropeplon Silveira, Floral. Mont. 12. 1928. Type: BRAZIL. Minas Gerais: Serra do Cipó, IV/1905, A. Silveira 345 (R!).

Eriocaulon intermedium Körn., Linnaea 27: 701. 1856. Type: INDIA. s.d., R. Wight 2369 (K "photo !").

Eriocaulon melanocephalum Kunth, Enum. pl. 549. 1841. Type: BRAZIL. São Paulo, s.d., Sellow 5850 (B “photo !”).
Eriocaulon schippii Standl. ex Moldenke, N. Amer. Fl. 19: 34. 1937. Type: HONDURAS, 11/IX/1930, W. A. Schippii 647 (B "photo !").

Eriocaulon usterianum Beauv. Bull. Herb. Boiss. sér. II. 8, p.284. 1908. Type: Brazil, São Paulo: Serra da Cantareira, 5/IV/1907, A. Usteri s.n. (G “photo !”, K “photo !”).

This species is broadly distributed in America, Africa and Asia. In Brazil it occurs in the Amazon Forest (AM, PA and RO), Atlantic Forest (SP) and Cerrado (GO, MG, and MT). It is submerged fixed. Because this species has a large extent of geographic occurrence, the conservation rating of Least Concern (LC) is proposed.

Eriocaulon setaceum can be recognized by: flexuos stem; linear, 1 nerved leaves; hemispherical capitula; staminate flowers with olivaceous, glabrous and deeply concave sepals that surpass the corolla.

Selected material: BRAZIL. Mato Grosso, 31/III/1968, fl., D. Philcox \& B. Freeman 4639 (UB).

48. Eriocaulon silveirae Moldenke, Known Geogr. Distrib. Eriocaulac. 62. 1946.

Eriocaulon longipedunculatum Silveira, Floralia montium 1: 15. 1928. Type: BRAZIL. Minas Gerais: between Formiga and Candeias, X/1921, A. Silveira 723 (R!) nom. illeg.

This species occurs in the Cerrado (MG). It is emergent, living along the banks of streams. It was not found in conservation units. Because this species has a small extent of geographic occurrence $\left(<100 \mathrm{~km}^{2}\right)$, only one location known, and it suffers an increasing of human pressure with continuing decline of area of occupancy, the conservation rating of Critically Endangered category (CRB1) is proposed.

Eriocaulon silveirae can be recognized by: robust habit; lanceolate, ca. 100 nerved and $2 \mathrm{~cm}$ wide leaves, longer than spathe; closed spathe with truncate apex; hemispherical to spherical capitula; cream-colored involucral bracts; staminate and pistillate flowers with ventral petal longer than the laterals one.

49. Eriocaulon spongiosifolium Silveira, Arq. Mus. Nac. Rio de Janeiro 23: 161. 1921. Type: BRAZIL. São Paulo: Rio Claro, XII/1888, A. Lofgreen 1197 (R!, SP).

This species occurs in the Cerrado (SP). It is amphibious, living along river banks. It was not found in conservation units. Because this species has a small extent of geographic occurrence $\left(<100 \mathrm{~km}^{2}\right)$, only one location known, and it suffers an increasing of human pressure with continuing decline of area of occupancy, the conservation rating of Critically Endangered category (CRB1) is proposed.

Eriocaulon spongiosifolium can be recognized by: robust habit; lanceolate, ca. 100 nerved and $2 \mathrm{~cm}$ wide, flat leaves, longer than spathe, with smooth transition from the sheath 
to the blade; slit spathe with acute apex; hemispherical to spherical, compact capitula; cream-colored involucral bracts that surpass the diameter of capitula and oblong, creamcolored floral bracts.

50. Eriocaulon spruceanum Körn., Fl. Bras. 3(1): 488. 1863. Type: BRAZIL. X/1852-I/1953, Spruce 2607 (F, G "photo !", NY "photo!").

Eriocaulon spruceanum f. amphibium Herzog, Repert. Spec. Nov. Regni Veg. 29: 203. 1931. Type: BRAZIL. Amazonas: Rio Papurí, 7/X/1928, Luetzelburg 22796, 23007, 23017, 23870, 23882 (R!).

Eriocaulon spruceanum f. fluitans Herzog, Repert. Spec. Nov. Regni Veg. 29: 203. 1931. Type: BRAZIL. Amazonas: Cururú, Uapés River, Luetzelburg n. 23251 a 23257 (?).

Eriocaulon spruceanum f. viviparum Moldenke, Phytologia 18: 342. 1969. Type: COLOMBIA. Meta: La Macarena: Guayabero River, I-III/1959, H. Garcia-Barriga \& R. J. Mejia 17096 (NY "photo!").

This species occurs in the Amazon Forest (AM) and Colombia. It is submerged fixed. It was not found in conservation units. Because this species has a large extent of geographic occurrence, the conservation rating of Least Concern (LC) is proposed.

Eriocaulon spruceanum can be recognized by: membranaceous leaves, longer than spathe; hemispherical capitula; involucral bracts cream-colored; pistillate flowers with asymmetrical and winged sepals.

51. Eriocaulon tenuifolium Klotzsch ex Körn., Fl. Bras. 3(1): 496. 1863. Type: GUYANA. Papira, II/1842, Schomburgk 448 (B "photo !" [B100244388], K "photo !"). Papira, III/1842, Schomburgk 285 (?).

Eriocaulon brevifolium Klotzsch ex Körn. Fl. Bras. 3(1): 496. 1863. Type: GUYANA, s.d., Schomburgk 107 (B “photo !").

This species occurs in the Amazon Forest, in cerrado vegetation (RR) and in Guyana. It is emergent, living in temporarily flooded locations. It was found in "Parque Nacional do Viruá" conservation unit. This species has a small area of occupancy and few locations are known, but it does not suffer decline of extent occurrence, occupancy area or population. Because this, the conservation rating of Least Concern (LC) is proposed.

Eriocaulon tenuifolium can be recognized by: robust habit; membranaceous leaves, longer than or equal to sphate; hemispherical, compact, 8-15 capitula and staminate flowers with ventral petal longer than the lateral ones.

52. Eriocaulon ulaei Ruhland, Pflanzenr. 4(30): 47. 1903. Type: BRAZIL, s.l., I/1889, E. Ule 1315 (B “photo !", F).

This species occurs in the Atlantic Forest, in Restinga vegetation (SC). It is amphibious, living in temporarily flooded locations. It was not found in conservation units. Because this species has a small extent of geographic occurrence $\left(<5,000 \mathrm{~km}^{2}\right)$, few locations are known $(\leq 5)$ and it suffers an increasing of human pressure with continuing decline of area of occupancy, the conservation rating of Endangered Category (ENB1) is proposed.

Eriocaulon ulaei can be recognized by: robust habit; lanceolate, with ca. 50 nerved and $1 \mathrm{~cm}$ wide leaves, longer than spathe, with spiral alternate arrangement; slit spathe with laciniate apex; hemispherical to spherical capitula and lanceolate, cream-colored floral bracts.

According to the protologue, E. ulaei was collected in the state of Rio de Janeiro. The label of the type indicates the date of collection (January 1889) but it does not mention the locality where the specimen was collected. In the same period, Ule collected Acnistus ulaei Dammer (Ule $1010 \mathrm{RB}$ ) in the state of Santa Catarina. This information indicates that the type of E. ulaei was collected in this state. The occurrence of this species in the state of Rio de Janeiro is unconfirmed as stated in the checklist of species from Brazil (Giulietti et al. 2013).

Selected material: BRAZIL. Santa Catarina, 27/II/1952, fl., L. Smith \& R. Reitz 5876 (R).

53. Eriocaulon weddellianum (Moldenke) A. Oliveira nom. nov. et stat. nov.

Eriocaulon sellowianum var. longifolium Moldenke, Phytologia 3: 417. 1951. Type: BRAZIL. Goiás: Salina, s.d., Weddell 2138 (BR "photo !").

This species occurs in the Cerrado (GO). It is amphibious, living in temporarily flooded locations. It was not found in conservation units. Because this species has a small extent of geographic occurrence $\left(<20,000 \mathrm{~km}^{2}\right)$, with few locations known, and it suffers an increasing of human pressure with continuing decline of area of occupancy, the conservation rating of Vunerable (VUB1) is proposed.

Eriocaulon weddellianum can be recognized by: incrassate leaves; brownish floral bracts with acuminate or aristate apex and staminate flowers with ovate ventral petal, ca. 1 $\mathrm{mm}$ longer than the lateral petals.

In the protologue, Eriocaulon sellowianum var. longifolium was distinguished from the typical variety by membranaceous and longer leaves, but analyses of the type do not corroborate this information. The leaves of Weddell's specimen (2138) are as incrassate as the typical variety. However, this variety has an exclusive and stable set of characters states, justifying the elevation of this taxon to species rank. Because the binomen Eriocaulon longifolium is preoccupied, the specific epithet "weddellianum" was chosen in honor of the collector of the type, Hugh Weddell (1819-1877 †), an Anglo-French botanist, physician, and explorer of the Brazilian flora (Stafleu \& Cowan 1976-1988).

Selected material: BRAZIL. Goiás: Cristalina, 23/ II/1998, fl., Proença et al. 1966 (UB). 


\section{Conclusion}

We recognize 53 species of Eriocaulon from Brazil. We propose the synonymization of eight species and five varieties: Eriocaulon candidum Moldenke has been considered a synonym of E. modestum Kunth, E. cipoense Silveira a synonym of E. aquatile Körn., E. damazianum Beauverd a synonym of E. cinereum R. Br., E. paludicola Silveira a synonym of E. cabralense Silveira, E. rosulatum Körn. a synonym of E. sellowianum Kunth, E. vaginatum Körn. a synonym of E. ligulatum (Vell.) L. B. Smith, E. reitzii Moldenke a synonym of E. magnificum, and E. singulare Moldenke a synonym of E. magnum Abbiatti. Likewise, Eriocaulon sellowianum var. minor Moldenke and E. sellowianum var. paranense Moldenke do not show differences from their respective autonyms. Eriocaulon magnificum var. goyazense Moldenke also is considered a synonym of E. ligulatum, E. gibbosum var. mattogrossense Ruhland a synonym of $E$. alto-gibbosum Ruhland, and E. steyermarkii var. bahiense Moldenke a synonym of E. modestum. We also propose the elevation to species status of five taxa: Eriocaulon aquatile var. latifolium Moldenke to E. multiscapum (Moldenke) A. Oliveira, E. ligulatum var. dimerum Giul. \& Miranda to E. dimerum (Giul. \& Miranda) A. Oliveira, E. gibbosum var. longifolium Körn. to E. gardnerianum (Körn.) A. Oliveira, E. sellowianum var. longifolium Moldenke to E. weddelianum (Moldenke) A. Oliveira, and E. ulaei var. radiosa Ruhland to $E$. radiosum (Ruhland) A. Oliveira.

Forty three species are endemic to Brazil. Four taxa also occur in neighboring countries to the south, Argentina, Paraguay, and/or Uruguay (Eriocaulon arechavaletae Herter, Eriocaulon leptophyllum Kunth, Eriocaulon magnum, and Eriocaulon sellowianum). Four species also occur to the north in Colombia, Venezuela, and/or Guyana (Eriocaulon guyanense, Eriocaulon humboldtii, Eriocaulon spruceanum, and Eriocaulon tenuifolium). Only Eriocaulon cinereum and Eriocaulon setaceum are more widely distributed, mainly in tropical areas.

Despite our efforts to improve the taxonomy of Eriocaulon from Brazil, we recognize that some problems could not be completely resolved here. However, we think that most of them have been clarified or identified as needing to be addressed in the near future.

\section{Acknowledgments}

We are grateful to the curators of the herbaria $\mathrm{BHCB}$, CAL, CESJ, HUEFS, HUFU, INPA, UB, OUPR, P, R, RB, SP and SPF. To Gustavo Gritz, Wilson Costa, Ricardo Moura and Josele Paz for their help in the field. To Ana Maria Giulietti, Paulo Takeo Sano and the anonymous reviewers, for valuable suggestions on the manuscript. To Janet W. Reid for the English revision. This study was supported by grants from CAPES to A.L.R.O. and from CNPq to C.P.B. (PROTAX 562251/2010-3).

\section{References}

Bongard GH. 1831. D' Eriocaulon du Brasil. Memoires de l' Academie Imperiale des Sciences de St. Petersbourg Sér. 6, Sci. Math. Vol. 1. Saint Petesburg, L'Imprimerie de L'Acádemie Imperiale des Sciences.

Costa MAS, Giulietti AM. 1999. Eriocaulaceae. Vol. 1. In: Ribeiro JELS, Hopkins MJG, Vicentini A, et al. (eds.) Flora da Reserva Ducke: Guia de identificação das plantas vasculares de uma floresta de terra-firme na Amazônia Central. Manaus, INPA. p. 692-692.

Davis JI, Nixon KC. 1992. Populations, genetic variation and the delimitation of phylogenetic species. Systematic Biology 41: 425-435.

Ferreira CSAM, Trovó M, Forzza RC. 2011. A Família Eriocaulaceae no Parque Estadual do Ibitipoca, Minas Gerais, Brasil. Boletim de botânica da Universidade de São Paulo 29: 19-35.

Giulietti AM. 1978a. Os gêneros Eriocaulon e Leiothrix na Serra do Cipó. PhD Thesis, Universidade Estadual de São Paulo, Brazil.

Giulietti AM. 1978b. Modificações taxonômicas no gênero Eriocaulon L. Boletim de botânica da Universidade de São Paulo 6: 39-47.

Giulietti AM. 1986. Eriocaulaceae. In: Harley RM, Simmons N. (eds.) Florula of Mucugê. Chapada Diamantina - Bahia, Brazil. Londres, Kew: Royal Botanic Gardens. p. 61-69.

Giulietti AM. 2012. Eriocaulon. In: Wanderley MGL, Martins SE, Romanini RP, et al. (eds.) Flora de São Paulo. Vol. 7. São Paulo, Instituto de Botânica. p. 173-200.

Giulietti, A.M, Hensold, N. 1987. Flora da Serra do Cipó, Minas Gerais: Eriocaulaceae, caracterização e lista de espécies. Boletim de botânica da Universidade de São Paulo 9: 112-116.

Giulietti AM, Hensold N. 1990. Padrões de distribuição geográfica dos gêneros de Eriocaulaceae. Acta Botanica Brasilica 4: 133-158.

Giulietti AM, Parra LR. 1995. Eriocaulaceae. In: Stannard B. (ed.) Flora of the Pico das Almas: Chapada Diamantina, Bahia, Brazil. Londres, Royal Botanic Gardens: Kew. p. 684-704.

Giulietti AM, Sano PT, Costa FN, et al. 2013. Eriocaulaceae. In: Lista de Espécies da Flora do Brasil. Jardim Botânico do Rio de Janeiro. http:// floradobrasil.jbrj.gov.br/2010/FB007539. 12 Nov. 2013.

Giulietti AM, Wanderley MGL, Longhi-Wagner HM, Pirani JR, Parra LR. 1996. Estudos em sempre-vivas: taxonomia com ênfase nas espécies de Minas Gerais, Brasil. Acta Botanica Brasilica 10: 329-377.

Govaerts R. 2006. World checklist of Eriocaulaceae. Kew, The Board of Trustees of the Royal Botanic Gardens. http://www.kew.org/wcsp/. 10 Mar. 2012.

Hind DJN. 2012. Catalogue of Brazilian Plants: a transcription of George Gardner's manuscript. Kew, Royal Botanic Gardens.

IBGE - Instituto Brasileiro de Geografia e Estatística. 2004. Mapa dos biomas do Brasil. ftp://ftp.ibge.gov.br/Cartas_e_Mapas/Mapas_Murais/ 07 Sep. 2013.

IBGE - Instituto Brasileiro de Geografia e Estatística. 2014a. http:// biblioteca.ibge.gov.br/visualizacao/dtbs/minasgerais/januaria.pdf. 10 Feb. 2014.

IBGE - Instituto Brasileiro de Geografia e Estatística. 2014b. Elaboração CONTÉCNICA - base Plano da Bacia do Rio Una - Secretaria de Recursos Hídricos de Pernambuco. http://www.museudouna.com. br/riouna.htm. 05 Feb. 2014.

IUCN - International Union for Conservation of Nature. 2012. IUCN Red List Categories and Criteria: Version 3.1. 2nd edn. Gland, IUCN.

Körnicke F. 1863. Eriocaulaceae. Vol. 3. In: Martius KP, Eichler AG, Urban I. (eds.) Flora Brasiliensis. Monachii. Typographia Regia. p. 273-507.

Kunth CS. 1841. Eriocaulaceae. Vol. 3. In: Kunth, CS (ed.). Enumeratio Plantarum Omnium Hucusque Cognitarum. Library of New York Botanical Garden. p. 492-580.

Miranda EB, Giulietti AM. 2001. Eriocaulaceae no Morro do Pai Inácio (Palmeiras) e Serra da Chapadinha (Lençóis), Chapada Diamantina, Bahia, Brasil. Sitientibus, Série Ciências Biológicas 1: 15-32.

Moldenke HN, Smith LB. 1976. Eriocauláceas. Flora Ilustrada Catarinense. Itajaí, Herbário Barbosa Rodrigues.

Moraes PLR. 2008. The Lauraceous collection of Friedrich Sellow. Komarovia 6: 1-68.

Oliveira ALR, Bove CP. 2011. Two new species of Eriocaulon from the Tocantins-Araguaia River basin, Brazil. Systematic Botany 36: 605-609. 
Queiroz K. 2007. Species concepts and species delimitation. Systematic Biology 56: 879-886.

Ruhland W. 1901. Eriocaulaceae. Botanische Jahrbücher für Systematik 30: 147.

Ruhland W. 1903. Eriocaulaceae. Vol. 4. In: Engler A. (ed.) Das Pflanzenreich. Berlin, H.R. Engelmann-Verlag. p. 1-294.

Silveira AA. 1908. Flora e Serras Mineiras. Belo Horizonte, Imp. Off.

Silveira AA. 1928. Floralia montium. Vol. 1. Belo Horizonte, Imp. Off.

Stafleu FA, Cowan RS. 1976-1988. Taxonome Literature. 2nd. edn. Utrecht, Bohn, Scheltema \& Holkema.
SPECIESLINK. 2014. http://www.splink.org.br/ 24 Oct. 2014.

Thiers B. Continuously updated. Index Herbariorum: A global directory of public herbaria and associated staff. New York Botanical Garden's Virtual Herbarium. http://sweetgum.nybg.org/ih 12 Dec. 2013.

Urban I. 1906. Vitae itineraque collectorum botanicorum, Notae collaboratorum biographicae, Flora Brasiliensis ratio edendi chronologica, Systema Index Familiarum. Vol. 1. In: Martius KP, Eichler AG, Urban I. (eds.) Flora Brasiliensis. Monachii. Typographia Regia p. 1-268. Vellozo JMC. 1827. Flora fluminensis. Vol 1. Paris, A. Senefelder. 